\title{
Antimicrobial peptides discovered in the black tiger shrimp Penaeus monodon using the EST approach
}

\author{
Premruethai Supungul ${ }^{1}$, Sirawut Klinbunga ${ }^{2}$, Rath Pichyangkura ${ }^{1}$, Ikuo Hirono ${ }^{3}$, \\ Takashi Aoki ${ }^{3}$, Anchalee Tassanakajon ${ }^{1, *}$
}

${ }^{1}$ Shrimp Molecular Biology and Genomics Laboratory, Department of Biochemistry, Faculty of Science, Chulalongkorn University, Bangkok 10330, Thailand

${ }^{2}$ Marine Biotechnology Research Unit, National Center for Genetic Engineering and Biotechnology (BIOTEC), National Science and Technology Development Agency (NSTDA), 113 Klong 1, Klong Luang, Prathumthani 12120, Thailand

${ }^{3}$ Laboratory of Genome Science, Graduate School of Marine Science and Technology, Tokyo University of Marine Science and Technology, Tokyo 108-8477, Japan

\begin{abstract}
Two cDNA libraries were prepared from hemocytes of normal and Vibrio harveyichallenged black tiger shrimp Penaeus monodon. A total of 1062 expressed sequence tag (EST) clones were sequenced unidirectionally. ESTs representing the antimicrobial peptide (AMP) homologues, antilipopolysaccharide factors (ALF), penaeidins and crustins were discovered. They predominated among immune-related genes, representing $29.2 \%$ and $64.0 \%$ of the normal and challenged libraries, respectively. Several types of each AMP homologue were found. Sequence alignments of ALF in P. monodon (ALFPm 1 to 5) implied possible alternative splicing of different exons at both $\mathrm{NH}_{2}$ and COOH-termini. Only one major type of penaeidin (penPm3) was found in P. monodon. In addition, crustin homologues (crusPms1 to 4) and a newly identified glycine-rich antibacterial peptide (GAMPPm1) were also isolated and characterized. Using RT-PCR analysis, expression of ALF, penaeidin and crustin transcripts was detected in various tissues but the main expression site was in hemocytes. Expression of these antimicrobial peptides in $P$. monodon subjected to $V$. harveyi challenge revealed a significant increase in expression of ALFPms $(p<0.05)$ but a decrease in expression of crustins and penaeidins.
\end{abstract}

KEY WORDS: Antimicrobial peptides $\cdot$ Penaeus monodon $\cdot$ Hemocytes $\cdot$ RT-PCR $\cdot$ EST

\section{INTRODUCTION}

Farming of the black tiger shrimp Penaeus monodon has been the most important aquacultural activity in Thailand for the last 2 decades. The country has contributed at least $20 \%$ of the total global aquacultural production of $P$. monodon annually (Rosenberry 2003). Nevertheless, the production of farmed shrimp is regularly affected by outbreaks of infectious disease caused by bacteria and viruses (Lightner \& Redman 1998, Bachere et al.
2000). Genetic selection and breeding programs to improve brood stock performance and seed production of $P$. monodon in Thailand have been conducted for a period of time (Jarayabhand et al. 1998, Withyachumnarnkul et al. 1998). Although growth rate is the desired trait most frequently targeted in penaeid shrimp (Hetzel et al. 2000, Argue et al. 2002, Goyard et al. 2002), selection for disease resistance has also been proposed to overcome low production efficiency associated with disease outbreaks (Bachere et al. 1995, Bachere et al. 2000). 
Efficient strategies for quantitative evaluation and monitoring of immune related genes in $P$. monodon would be useful in future selection of resistance lines.

Host defense in crustaceans and other invertebrates relies on innate, non-adaptive mechanisms (Lemaitre et al. 1997). Antimicrobial peptides (AMPs) are generally small cationic molecules that play an important role in the innate immune defense against bacterial and fungal pathogens (Boman 1995, Hancock \& Scott 2000) but some also exhibit antiviral or antiparasitic activity (Murakami et al. 1991, Hancock \& Diamond 2000, Pan et al. 2000) and even antitumor activity (Cruciani et al. 1991). AMPs have been isolated from diverse organisms ranging from plants and insects to animals (Bartlett et al. 2002). Their primary structures are highly variable but they share some common features including an amphipathic secondary structure, cationic properties at physiological pH and a broad spectrum of antimicrobial activity (Bulet et al. 1999, Lehrer \& Ganz 1999). Most antimicrobial peptides are membrane active agents and are either inducible or constitutive. They kill microbial pathogens by permeating and disrupting the outer cell membrane (Shai 1999, Yeaman \& Yount 2003).

Previously, a small basic protein, anti-lipopolysaccharide factor (ALF) exhibiting strong antibacterial activity against Gram-negative bacteria, was isolated and characterized from hemocytes of the horseshoe crab (Morita et al. 1985, Wainwright et al. 1990). More recently, crustacean AMPs including penaeidins, cysteine- and proline-rich antibacterial proteins and astacidin 1 have been isolated and characterized from the white shrimp Litopenaeus vannamei (Destoumieux et al. 1997, Bachere et al. 2000), the crab Carcinus maenas (Schnapp et al. 1996, Relf et al. 1999) and the crayfish Pacifastacus leniusculus (Lee et al. 2002), respectively. Moreover, homologues of a cysteine-rich $11.5 \mathrm{kDa}$ antibacterial peptide crustin from the shore crab were identified in L. vannamei and L. setiferus while homologues of penaeidin 2 and bacternectin 11 were identified in the kuruma shrimp Marsupenaeus japonicus using the expressed sequence tag (EST) approach (Bartlett et al. 2002).

We established cDNA libraries from hemocytes of normal and of Vibrio harveyi-challenged Penaeus monodon. Several immune-related genes were identified, including AMP homologues of ALF, penaeidins and crustins. The EST sequences were analyzed and compared to those reported in other species. Tissue distribution and expression of these AMP transcripts were examined in response to $V$. harveyi challenge with P. monodon.

\section{MATERIALS AND METHODS}

Experimental shrimp, hemocyte collection and total RNA preparation. Penaeus monodon juveniles (16 to $20 \mathrm{~g}$ body weight) were purchased from local farms in Chachoengsao, eastern Thailand and divided to 2 groups: normal and challenged shrimp. Vibrio harveyi 1526 (provided by Shrimp Culture Research Center, Charoenpokaphand Group of Companies, Thailand) was cultured in tryptic soy broth with $1 \%(\mathrm{w} / \mathrm{v}) \mathrm{NaCl}$ at $30^{\circ} \mathrm{C}$ for 8 to $10 \mathrm{~h}$ and diluted $1: 100$ with sterile normal saline solution [0.8\% (w/v) $\mathrm{NaCl}]$. The number of bacterial cells $\mathrm{ml}^{-1}$ present in the inoculum was determined by plate count method in tryptic soy agar with $1 \%(w / v) ~ N a C l$ (modified from Austin 1988). A known quantity $(100 \mu \mathrm{l})$ of the inoculum $\left(10^{6} \mathrm{cfu} \mathrm{ml}^{-1}\right)$ were injected intramuscularly into the 4 th ventral abdominal segment of each challenged shrimp.

For construction of cDNA libraries, approximately $10 \mathrm{ml}$ hemolymph from 10 normal and 10 challenged shrimp (48 h post-infection) was collected individually in an anticoagulant solution of $10 \%(\mathrm{w} / \mathrm{v})$ of trisodium citrate dihydrate adjusted to $\mathrm{pH} 7.0$ by addition of citric acid. Hemocytes were separated from the plasma of each shrimp by centrifugation at $800 \times g$ for $10 \mathrm{~min}$ at room temperature. Hemocytes from each group were pooled and total RNA was immediately extracted using TRIZOL reagent (GIBCO BRL). Extracted RNA was kept in $75 \%$ ethanol at $-80^{\circ} \mathrm{C}$ until needed.

To determine tissue-specific expression of AMP transcripts, total RNA was isolated from hemocytes, hearts, gills, lymphoid organs, intestines and hepatopancreata of freshly killed unchallenged juvenile Penaeus monodon. For a time-course study of mRNA expression 25 juvenile $P$. monodon were injected with Vibrio harveyi $\left(10^{5} \mathrm{cfu}\right)$. Approximately $5 \mathrm{ml}$ hemolymph was collected from 5 individuals and pooled at 3, 6, 12, 24 and $48 \mathrm{~h}$ post-injection. Unchallenged shrimp (5) were used as the control. This time-course experiment was repeated 3 times.

Construction of cDNA libraries and EST analysis. Two cDNA libraries were constructed, 1 from hemocytes of normal shrimp (Supungul et al. 2002) and 1 from Vibrio harveyi-challenged shrimp (Supungul 2002). Insert sizes of recombinant clones were verified by colony PCR or by digestion of extracted plasmids (Supungul 2002). EST clones containing insert sizes > 500 bp were randomly selected and partially sequenced unidirectionally using a Thermo Sequenase Fluorescent Labeled Primer Sequencing Kit (Amersham Pharmacia Biotech) with M13 forward (5'-CAC GAC GTT GTA AAA CGA C-3') or reverse (5'-GGA CAA CAA TTT CAC ACA GG-3') primers on an automated DNA sequencer LC4000 (LICOR). 
Semiquantitative RT-PCR and tissue-specific expression analysis. The first-stranded cDNA was synthesized from total RNA of hemocytes using an AMV Reverse Transcriptase First-Strand cDNA Synthesis Kit (Life Sciences). Semi-quantitative RT-PCR was carried out in a $25 \mu \mathrm{l}$ reaction volume containing $10 \mathrm{mM}$ Tris$\mathrm{HCl}_{1} \mathrm{pH} 8.8,50 \mathrm{mM} \mathrm{KCl}, 0.1 \%$ Triton X-100, an appropriate $\mathrm{MgCl}_{2}$ concentration $(1.5,2.5$ and $4 \mathrm{mM}$ for crustins, penaeidins and ALF, respectively), $0.2 \mathrm{mM}$ of each dNTP, $50 \mathrm{ng}$ of the first-stranded cDNA template, $1 \mathrm{U}$ of Dynazyme ${ }^{\mathrm{TM}}$ II DNA polymerase and $0.5 \mathrm{M}$ of each primer. Primers for amplification of ALF was designed based on the sequences of ALFPm3 whereas those of penaeidin can amplify all penaeidin variants. Primers for amplification of crustin was designed based on the sequences of a complete ORF of CrusPm1. Primers were 5'-CGC CAG CAA GAT CGT AGG GTT G-3' and 5'-AGG CCT ATG AGC TGA GCC ACT G-3' for ALF, 5'-AGG ATA TCA TCC AGT TCC TG-3' and 5'-ACC TAC ATC CTT TCC ACA AG$3^{\prime}$ for penaeidins and $5^{\prime}$-TCC CTG GAG GTC AAT TGA GTG-3' and 5'-AGT CGA ACA TGC AGG CCT ATC C-3' for crustins, while primers 5'-GCT TGC TGA TCC ACA TCT GCT-3' and 5'-ACT ACC ATC GGC AAC GAG A-3 served for the $\beta$-actin internal control. Semiquantitative RT-PCR was standardized according to Marone et al. 2001. PCR was initially performed by pre-denaturation at $94^{\circ} \mathrm{C}$ for $1 \mathrm{~min}$ followed by 24 cycles (ALF and crustins) or 27 cycles (penaeidins) of $94^{\circ} \mathrm{C}$ denaturation for $30 \mathrm{~s}, 53^{\circ} \mathrm{C}$ annealing for $30 \mathrm{~s}$ and $72^{\circ} \mathrm{C}$ extension for $1 \mathrm{~min}$. A final extension was carried out at $72^{\circ} \mathrm{C}$ for $5 \mathrm{~min}$. Amplicons were electrophoretically analyzed through $1.4 \%$ agarose gels.

For tissue-specific expression, RT-PCR of each transcript was carried out for 40 cycles to reach a plateau level of amplification using comparable conditions as those described above. An 18S rRNA gene amplicon was included as a positive control (primers 5'-GAG ACG GCT ACC ACA TCT AAG-3' and 5'-ATA CGC TAG TGG AGC TGG A-3'). Five $\mu$ of each PCR sample were size-fractionated through a $1.5 \%$ gel and visualized with a UV transilluminator after ethidium bromide staining.

Data analysis. EST sequences were compared with data at GenBank using BLASTN and BLASTX (Altschul et al. 1997, available at www.ncbi.nlm.nih. gov). Significant probabilities and numbers of matched nucleotides/ proteins were considered when E-values were $<10^{-4}$ and the match included $>100$ nucleotides for BLASTN or $>10$ amino acid residues for BLASTX. Deduced amino acid sequences of ALF, crustin and penaeidin homologues were translated using GENETYX and multiple alignments were carried out using CLUSTALX (Thompson et al. 1997). Aligned sequences were bootstrapped 1000 times using SEQBOOT. Sequence divergence between pairs of deduced pro- tein sequences was calculated using PRODIST. A bootstrapped neighbor-joining tree (Saitou \& Nei 1987) was constructed to illustrate the relationship among different sequences of each AMP using NEIGHBOR and CONSENSE. All phylogenetic programs described were routine in PHYLIP (Felsenstein 1993).

The AMP expression level in response to bacterial challenge was determined by a semi-quantitative RTPCR. The AMP transcript and the internal control ( $\beta$ actin) were amplified in the same reaction tube and the PCR product was semi-quantitatively analyzed at the exponential phase of amplification (Marone et al. 2001). The ratio between the intensity of electrophoresed target and $\beta$-actin gene products was recorded using a gel documentation system (GeneCam FLEX1, SynGene) and further quantified by Genetool Analysis Software. The time-course of expression for each transcript was normalized with that of $\beta$-actin (i.e. expression of $\beta$-actin at each interval was 100) and tested using 1-way analysis of variance (ANOVA) (Steel \& Torrie 1980) followed by Duncan's new multiple range test (Duncan 1955) using SPSS software.

\section{RESULTS AND DISCUSSION}

\section{Identification and characterization of genes encoding antimicrobial peptides in Penaeus monodon}

A total of 1062 clones from cDNA libraries established from hemocytes of normal (615 clones) and Vibrio harveyi-challenged Penaeus monodon (447 clones) were analyzed (Supungul 2002, Supungul et al. 2002). One hundred and fifteen clones $(10.8 \%)$ corresponded to 30 different genes identified as putative immunerelated genes (Table 1). ESTs homologues of AMP (ALF, crustins, penaeidins and lysozymes) were the most abundant, representing $29.2 \%$ and $64.0 \%$ of the putative immune genes found in the normal and $V$. harveyi-challenged libraries, respectively (Table 1). Penaeidins predominated among AMP in the normal library $(36.84 \%)$ followed by crustins and ALF $(26.3 \%$ each). In contrast, ALF predominated $(50.0 \%)$ in the challenged library while crustins $(25.0 \%)$ and penaeidins $(18.8 \%)$ were found at relatively lower levels. The abundance of these AMP in hemocytes of infected P. monodon particularly, suggested that they played a major role in host-defense against bacterial infection. In ESTs of cDNA libraries from hemocytes of normal Litopenaeus vannamei and L. setiferus, Gross et al. (2001) found that $14.3 \%$ and $26.6 \%$, respectively, encoded immune-related genes amongst which AMP were the most abundant $(86.1 \%$ in $L$. vannamei and $80.7 \%$ in L. setiferus). Penaeidins predominated (75.0\% in L. vannamei and $75.2 \%$ in L. setiferus) and 
Table 1. Penaeus monodon. Immune related genes isolated from haemocytes of normal and Vibrio harveyi-challenged shrimp

\begin{tabular}{|c|c|c|c|c|c|c|c|}
\hline Putative identification & Closest species & Probability & $\begin{array}{l}\text { Matched } \\
(\%)\end{array}$ & $\begin{array}{l}\text { Sequence } \\
\text { length } \\
\text { (bp) }\end{array}$ & $\begin{array}{l}\text { Frequency } \\
\text { (normal } \\
\text { shrimp) }\end{array}$ & $\begin{array}{l}\text { Frequency } \\
\text { (challenged } \\
\text { shrimp) }\end{array}$ & $\begin{array}{c}\text { Total } \\
\text { clones }\end{array}$ \\
\hline $\begin{array}{l}\text { 1. Antimicrobial molecules } \\
\text { antilipopolysaccharide } \\
\text { factor }\end{array}$ & a Limulus polyphemus & $7.00 \mathrm{E}-19$ & 64 & 512 & 5 & 16 & 21 \\
\hline Crustin & Litopenaeus setiferus & $1.00 \mathrm{E}-42$ & 65 & 515 & 5 & 8 & 13 \\
\hline penaeidin3a & Litopenaeus vannamei & $1.00 \mathrm{E}-18$ & 66 & 412 & 7 & 6 & 13 \\
\hline lysozyme & Mus musculus & $2.00 \mathrm{E}-26$ & 67 & 541 & 2 & 2 & 4 \\
\hline \multicolumn{8}{|c|}{ 2. ProPO systems and oxidative enzyme $\mathrm{e}^{\mathrm{b}}$} \\
\hline clottable protein & Penaeus monodon & $\mathrm{E}-130$ & 98 & 458 & 3 & 3 & 6 \\
\hline $\begin{array}{l}\text { cytosolic manganese } \\
\text { superoxide dismutase prec }\end{array}$ & $\begin{array}{l}\text { Callinectes sapidus } \\
\text { ursor }\end{array}$ & E-129 & 86 & 930 & \multicolumn{2}{|c|}{ superoxide dismutase precursor } & 1 \\
\hline glutathione peroxidase & Homo sapiens & $3.00 \mathrm{E}-18$ & 76 & 331 & 1 & - & 1 \\
\hline transglutaminase & Tachypleus tridentatus & $2.00 \mathrm{E}-48$ & 76 & 746 & 4 & - & 4 \\
\hline Peroxidase & Aedes aegypti & $1.00 \mathrm{E}-21$ & 52 & 747 & 1 & - & 1 \\
\hline prophenoloxidase & Penaeus monodon & $1.00 \mathrm{E}-51$ & 98 & 465 & 1 & - & 1 \\
\hline $\begin{array}{l}\text { prophenoloxidase } \\
\text { activating factor }\end{array}$ & Holotrichia diomphalia & $7.00 \mathrm{E}-18$ & 70 & 550 & 1 & 2 & 3 \\
\hline Catalase & Campylobacter jejuni & 3.00E-09 & 93 & 575 & 1 & - & 1 \\
\hline \multicolumn{8}{|l|}{ 3. Proteinases and inhibitor ${ }^{c}$} \\
\hline $\begin{array}{l}\text { Kazal-type serine } \\
\text { proteinase inhibitor }\end{array}$ & Pacifastacus leniusculus & $5.00 \mathrm{E}-31$ & 60 & 503 & 8 & 4 & 12 \\
\hline hemocyte protease-1 & Manduca Sexta & $1.00 \mathrm{E}-12$ & 57 & 700 & 1 & - & 1 \\
\hline $\begin{array}{l}\text { cathepsin B-like } \\
\text { cysteine proteinase }\end{array}$ & Sarcophaga perregrina & $6.00 \mathrm{E}-18$ & 88 & 659 & 1 & - & 1 \\
\hline serine protease & Pacifastacus leniusculus & $4.00 \mathrm{E}-79$ & 79 & & 1 & 1 & 2 \\
\hline Whey acidic protein & Trichosurus vulpecula & $5.00 \mathrm{E}-06$ & 48 & 712 & 1 & 1 & 2 \\
\hline \multicolumn{8}{|l|}{ 4. Heat shock protein ${ }^{\mathrm{d}}$} \\
\hline heat shock cognate 70 & Oncorhynchus mykiss & $9.00 \mathrm{E}-95$ & 76 & 772 & 1 & 1 & 2 \\
\hline heat shock protein 70 & Hydra magripapillata & $2.00 \mathrm{E}-56$ & 90 & 806 & 1 & 1 & 2 \\
\hline heat shock protein 90 & Gallus gallus & $9.00 \mathrm{E}-27$ & 70 & 618 & 2 & - & 2 \\
\hline \multicolumn{8}{|l|}{ 5. Other immune molecules ${ }^{\mathrm{e}}$} \\
\hline FC fragment of IgE & Homo sapiens & $5.00 \mathrm{E}-07$ & 67 & 533 & - & 1 & 1 \\
\hline protein $\mathrm{c}$ & Mus musculus & $3.00 \mathrm{E}-10$ & 63 & 708 & 1 & - & 1 \\
\hline protein-kinase c inhibitor & Bos taurus & $2.00 \mathrm{E}-38$ & 78 & 756 & 1 & - & 1 \\
\hline thymosin beta- 9 and beta 8 & Bos taurus & $2.00 \mathrm{E} 04$ & 77 & 706 & 2 & - & 2 \\
\hline thymosin beta-11 & Oncorhynchus mykiss & $4.00 \mathrm{E}-27$ & 64 & 872 & 3 & - & 3 \\
\hline perlucin & Haliotis cuniculus & $7.00 \mathrm{E}-16$ & 54 & 575 & 2 & - & 2 \\
\hline cyclophilin 18 & Oryctolagus cuniculus & $8.00 \mathrm{e}-58$ & 72 & 756 & 1 & - & 1 \\
\hline chaperonin containing & Homo sapiens & $9.00 \mathrm{E}-67$ & 77 & 637 & 3 & - & 3 \\
\hline $\begin{array}{l}\text { peptide-prolyl cis-trans } \\
\text { isomer } 5\end{array}$ & Drosophila melanogaster & $3.00 \mathrm{E}-68$ & 81 & 816 & 4 & 3 & 7 \\
\hline \multicolumn{8}{|c|}{$\begin{array}{l}\text { a'GenBank sequences BI784448, BI784449, BI018071, BI784451, CF415871, CD766060, BI784444, BI784445, CF415873, } \\
\text { BI784446, BI784459, BI784441, BI018079, BI018081 }\end{array}$} \\
\hline \multicolumn{8}{|c|}{$\begin{array}{l}\text { 'benBank sequences CF415874, BI784454, BI018091, BI018082, BI018083, BI018084, BI018093, BI018092, BI018090, } \\
\text { BI018087, BI784455, BI018085 }\end{array}$} \\
\hline \multicolumn{8}{|c|}{ 'GenBank sequences BI784456, BI018098, BI018075, BI018078, CF415875, CF415876, CF415872, BI784457 } \\
\hline \multicolumn{8}{|c|}{${ }^{\mathrm{d} G e n B a n k}$ sequences BI018100, BI018094, BI784458, BI018097, BI784452, BI018095, BI018096 } \\
\hline e'GenBank sequences BI784 & 4442, BI018099, BI018088, & I018086, CF4 & 415877, CF & 415878, CF4 & 15879, CF415 & 5880, CF4158 & 381 \\
\hline
\end{tabular}

mainly penaeidin 3. Crustins were the second most common AMP but comprised only $9.7 \%$ in L. vannamei and $4.1 \%$ in L. setiferus. Two ALF homologues were found in L. setiferus but none in L. vannamei. In con- trast, EST of penaeidin 2 precursor, lysozyme type $\mathrm{C}$ and bactinectin were found in normal and WSSVchallenged cDNA libraries of Marsupenaeus japonicus hemocytes (Rojtinnakorn et al. 2002). 


\section{Multiple genes encoding ALF in Penaeus monodon and possible alternative splicing}

ALF, has been reported from hemocytes of horseshoe crabs Limulus polyphemus and Tachypteus tridentatus (Morita et al. 1985, Aketagawa et al. 1986). They bind and neutralize lipopolysaccharides and have strong antibacterial effects on Gram negative Rtype bacteria (Wainwright et al. 1990).

Twenty one EST representing ALF were identified in Penaeus monodon. Of these, 17 contained complete open reading frames (ORF) of 252, 360, 369, 396 and 465 bp encoding 84, 120, 123, 132 and 155 deduced amino acids, respectively. These EST exhibited $57 \%$ to $65 \%$ amino acid homology with those of the horseshoe crab Tachypleus tridentatus and Limulus polyphemus. Sequence alignment revealed that at least 5 different types - ALFPm1 to ALFPm5, with accession numbers BI784448, BI784449, BI018071, BI784451 and CF415871, respectively - exist in P. monodon hemocytes (Fig. 1). These clones were re-sequenced 2 to 3 times to ensure accuracy of their nucleotide sequences.

ALFPm3 predominated (13 clones) and was found in both cDNA libraries. Other ALF (ALFPms1, 2, 4 and 5) were found only in the hemocyte library of challenged Penaeus monodon. A putative signal peptide of ALFPm 1, 2, 3 and 5 was located at the $\mathrm{NH}_{2}$-terminus between Ala/Gly (A/G) and Gln (Q). However, this putative cleavage site was not found in ALFPm4. All ALFPm contain 2 cysteine residues bracketing somewhat conserved amino acids within the loop that would result from their disulfide linkage (CRYSQRPSFYRWELYFNGRMWC for ALFPms 1 and 2 and CKFTVKPYLKRFQVYYKGRMWC for ALFPms3 to 5) (Fig. 1.). These differed from ALF in Limulus polyphemus and Tachypteus tridentatus [CHYR(V/I)(N/K)PT(V/F)(K/R)RLKWKY-KG-KFWC] (Fig. 1). This segment of the protein forms the basic face in the 3-dimensional structure of ALFTt that was proposed to play an important role in Lipid A binding (Hoess et al. 1993). Although ALFPm lacked some of the positively charged residues present in ALFTt, 5 residues in ALFPm 1 to 2 and 3 residues in ALFPm3 to 5, the arginine residue at the center of the segment and other positively charged residues were conserved. Moreover, we found that most of the bulky hydrophobic residues were conserved, and this implied a crucial structural role in this domain.

The N-terminus of ALFPm1 to 2, ALFPm3 to 5, and ALF of the horseshoe crabs were found to be divergent in their amino acid sequences. However, they all contained conserved hydrophobic amino acid residues at common positions along the primary structure. These residues formed a conserved hydrophobic face on the amphipathic $\beta$-helix 1 of ALF (Hoess et al. 1993), that may be involved in the membrane insertion ability of ALF. Nevertheless, heterogeneous ALFPm were found in Penaeus monodon hemocytes.

Pairwise alignment of ALFPm indicated $100 \%$ amino acid sequence homology between ALFPm1 and ALFPm2 (residues 1 to 82). As a result, ALFPm1 should be an allelic
ALF Pm1
ALF Pm2
ALF Pm3
ALF Pm5
ALF Pm4
ALF Lp1
ALF Tt
ALF Lp2

ALF Pm1
ALF Pm2
ALF Pm3
ALF Pm5
ALF Pm4
ALF $L p 1$
ALF Tt
ALF Lp2
ALF Pm1
ALF Pm2
ALF Pm3
ALF Pm5
ALF Pm4
ALF Lp1
ALF Tt
ALF Lp2

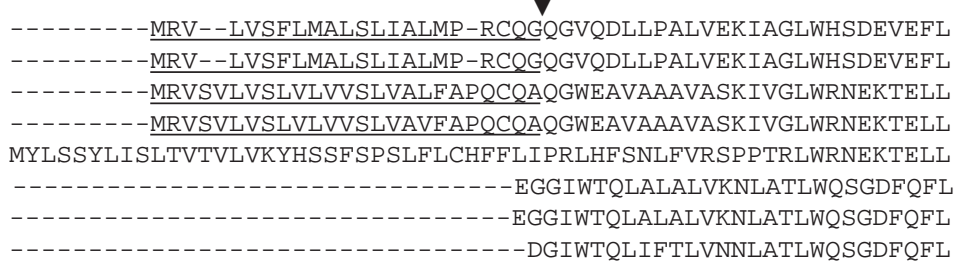
:. . ${ }^{\star} *$. . $::^{\star}$

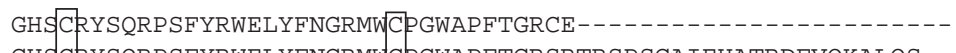
GHSCRYSQRP SFYRWELYFNGRMWCPGWAPFTGRSRTRSP SGAIEHATRDFVQKALQS-GHE CKF TVKPYLKRFQVYYKGRMWCE GWTAIRGEASTRSQSGVAGKTAKDFVRKAFQK-GHECKFTVKPYLKRF QVYYKGRMW C E GWD GHQRRSQHTQSVRGSWKD SQRLRSESFPERS GHE CKF TVKPYLKRFQVYYKGRMWCE GWTAIRGEASTRSQSGVAGKTAKDFVRKAFQK-GHE CHYRVNP TVKRLKWKYKGKFWCPSWTS I TGRATKSSRSGAVEHSVRDFVSQAKSS-GHE C HYRVNP TVKRLKWKYKGKFWCP SWTS I T GRA TKS SRS GAVEHSVRDFVSQAKSS-DHECHYRIKPTFRRLKWKYKGKFWCP SWTS ITGRATKSSRSGAVEHSVRNFVGQAKSS--

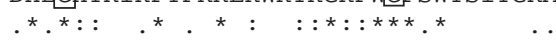

Fig. 1. Multiple alignments of ALF homologues in Penaeus monodon (ALFPm1 to 5) and those of Limulus polyphemus (ALFLp1 and 2) and Tachypleus tridentatus (ALFTt) (Aketagawa et al. 1986, Muta et al. 1987). * indicates amino acid identity and - indicates amino acid similarity. The putative signal peptides and a cleavage site in ALF$P m$ 1, 2, 3 and 5 are underlined and indicated by an arrowhead, respectively. The boxes indicate cysteine residues 
variant of ALFPm2 (Fig. 2A). In addition, perfect homology was observed for the $\mathrm{NH}_{2}$ terminal sequences (residues 1 to 79 ) of ALFPm3 to 5 (Fig. 2B-D) although polymorphism was found at the $\mathrm{COOH}$ terminus. On the other hand, ALFPm3 and ALFPm4 perfectly shared the COOH-terminal portion (residues 51 to 88). ALFPm3 to 5 shared a core sequence of LWRNEKTELLGHECKFTVKPYLKRFQVYYKGRMWCPGW but this sequence stretch was not found in ALFPm1 and 2, indicating that ALFPm may have been encoded from more than 1 locus. Polymorphism found among ALFPm3 to 5 ESTs may have resulted from alternative splicing of different exons in the $\mathrm{NH}_{2}$ and $\mathrm{COOH}$-terminal regions of ALF in Penaeus monodon.

Sequence divergences between different ALFPm were 0.0330 (ALFPm1 and ALFPm2) to 1.6257 (ALFPm2 and ALFPm5). Phylogenetic analysis indicated large genetic differences between ALFPm and their outgroups from Limulus polyphemus and Tachypleus tridentatus (Fig. 2E). At the intraspecific level, ALFPms1 to 5 can be phylogenetically allocated to 2 different groups: A (ALFPm1 and ALFPm2) and B (ALFPms3 to 5), where the molecular evolution from AFLPm4 to ALFPm5 (or vice versa) required contribution of ALFPm3 (Fig. 2E). This supports the hypothesis that ALFPm does not arise from a single copy nuclear gene but may be encoded by 2 different loci. Nevertheless, antibacterial peptides are typically encoded by single-copy genes (Hancock \& Diamond 2000). As a result, organization of ALFPm genes should be further characterized at the genomic level.

\section{One major penaeidin EST found in normal and challenged Penaeus monodon}

Penaeidins are a unique family of AMP previously reported in Litopenaeus vannamei. They exhibit antiGram-positive and antifungal activities (Destoumieux et al. 1999). Ten of 13 penaeidin ESTs isolated from Penaeus monodon hemocyte cDNA (Table 1) contain complete ORF. The deduced amino acid sequences suggested the existence of 3 penaeidin variants in $P$. monodon (pen $P m$ ). These variants contained an identical ORF of 225 bp coding for a 74 amino acid protein with 2 single amino acid variations at residues 34 and 64 (Fig. 3A). They were regarded as homologues (penPm3a, 3b and 3c, GenBank accession numbers BI784459, BI784441 and BI018079, respectively) of penaeidin3 of $L$. vannamei (pen $L v 3 \mathrm{a}$ ) with 48 to $50 \%$ sequence similarity. However, they did not contain a conserved chitin binding domain (C-X5-C-C-S-X2-G$\mathrm{X}-\mathrm{CG}-\mathrm{X} 5-\mathrm{C}$ ) as found in their homologue (Destoumieux et al. 2000) and common to some plant chitinbinding proteins (Raikhel et al. 1993). This suggested that penPm3a, 3b and 3c may not posses antifungal activity.

A putative signal peptide was predicted at the $\mathrm{NH}_{2}$ terminus comprising 19 amino acid residues that were almost identical to those of Litopenaeus vannamei (Fig. 3A). A proline-rich region was also found, containing a conserved PRP motif and 6 cysteine residues at the $\mathrm{COOH}$-terminal region as typically observed in L. vannamei (Destoumieux et al. 1997) and insects (Hetru et al. 1998). Pairwise sequence divergence between penPm3a, 3b and 3c was 0.0123 to 0.0276 . The bootstrapped neighbor-joining tree supports the classification of penPm3a, 3b and 3c as allelic variants rather than different isoforms (Fig. 3B).

\section{Crustins and a newly isolated Gly-rich antibacterial peptide}

Crustin was initially isolated and characterized in the shore crab Carcinus maenas as an $11.5 \mathrm{kDa}$ antibacterial peptide potentially acting against Gram positive bacteria (Relf et al. 1999). Recently, 6 and 3 complete ORF of crustins were identified from hemocyte cDNA libraries of Litopenaeus vannamei and L. setiferus, respectively (Bartlett et al. 2002).

Thirteen Penaeus monodon hemocyte clones (5 clones from normal shrimp and 8 clones from challenged shrimp, GenBank accession numbers CD766060, BI784444, BI784445, CF415873 and BI784446) significantly matched crustins of other crustaceans (Table 1). Two contained an identical, complete ORF of $435 \mathrm{bp}$ encoding a putative protein of 145 amino acid residues (crusPm1, accession no. CD766060) that showed $65 \%$ homology to a crustin of Litopenaeus sertiferus (crusLs, Fig. 4A). In addition, 3 different sequences (crusPm2 to 4) showed Gly-rich and Pro/Cys-rich sequences at the $\mathrm{NH}_{2}$ and $\mathrm{COOH}$ termini. Alignment of these ESTs with those from L. vannamei (crusLv) and L. setiferus (crusLs1 and crusLs2) revealed 12 conserved Cys residues and a consensus pattern of C1-X3-C2-X8-C3-C4-X16-C5X5/6-C6-X9/11/12/13-C7-X5-C8-X5-C9-C10-X3-C11$\mathrm{X} 5-\mathrm{C} 12$ where $\mathrm{X}$ is any amino acid residue and $\mathrm{Xn}$ is a stretch of $n$ residues.

An additional EST (called GAMPPm1, GenBank accession no. BI018079) significantly matched with crustins of Litopenaeus vannamei (E value $=6 \times 10^{-9}$ ) and exhibited 9 conserved Cys residues ( $\mathrm{C} 3$ to $\mathrm{C} 12$ ) following the consensus sequences of crustin homologues and a whey acidic protein (WAP) domain (conserved C5 to C12 forming 4 disulfide core, 4DSC). However, C1, C2 and C3 were replaced with Val, Gly and Glu, respectively. Therefore, it was not regarded as a member of the crustin group. Generally, proteins containing the WAP 
A

B

\section{C}

\section{D}

MRVLVSFLMALSLIALMPRCOGOGVODLLPALVEKIAGLWHSDEVEFLGHSCRYSORPSF MRVLVSF LMALSLIALMPRCQGQGVQDLLPALVEKIAGLWHSDEVEFLGHSCRYSQRPSF

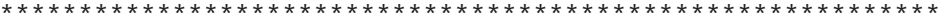

YRWELYFNGRMWCP GWAPFTGRSRTRSP SGA IEHATRDFVQKALQSNLI TEEDARIWLEH YRWELYFNGRMWCP GWAPFTGRCE-

MYLSSYLISLTVTVLVKYHSSF SP SLF LCHFF LIPRLHF SNLFVRSPP TRLWRNEKTELL MRVSVLVSLVLVVSLVALFAP QCQAQGWEAVAAAVASKIVGLWRNEKTELL

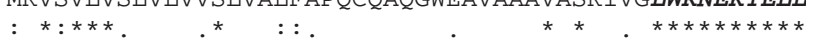

GHECKFTVKPYLKRFQVYYKGRMWCPGWTAIRGEASTRSQSGVAGKTAKDFVRKAFQKGL GHECKFTVKPYLKRFQVYYKGRMWCPGWTAIRGEASTRSQSGVAGKTAKDFVRKAFQKGL

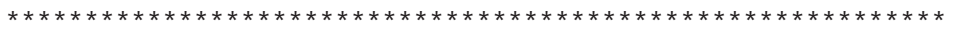

ISQQEANQWLSS

ISQQEANQWLSS

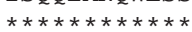

MRVSVLVSLVLVVSLVAVFAPQCQAQGWEAVAAAVASKIVGLWRNEKTELLGHECKFTVK MRVSVLVSLVLVVSLVALF AP QCQAQGWEAVAAAVASK IVGLWRNEKTELLGHECKFTVK

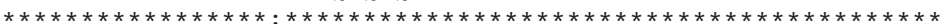

PYLKRFQVYYKGRMWCP GWDGHQRRSQHTQSVRGSWKD SQRLRSESFPERSHLSTGGQPV PYLKRFQVYYKGRMWCP GWTAIRGEASTRSQSGVAGKTAKDFVRKAFQKGLISQQEANQW

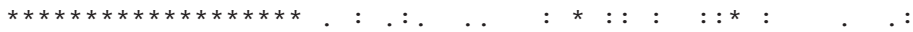

AQLIGLLLYEELSVF SCSWQWKLYHFDFLCFSFQY LSS-

--------MRVSVLVSLVLVVSLVAVFAPQCQAQGWEAVAAAVASKIVGLWRNEKTELL MYLSSYLISLTVTVLVKYHSSF SP SLF LCHFF LIPRLHF SNLFVRSPP TRLWRNEKTELI

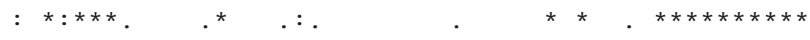

GHECKFTVKPYLKRFQVYYKGRMWCPGWDGHQRRSQHTQSVRGSWKDSQRLRSESFPERS GHECKFTVKPYLKRFQVYYKGRMWCPGWTAIR--------------------GEASTRS

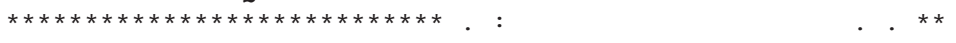

HLSTGGQPVAQL IGLLLYEELSVF SCSWQWKLYHFDFLCF SFQY QSGVAGKTAKDFVRKAFQKGLISQQEANQWLSS----------: ..* :..: : : : : * . : *

$\mathbf{E}$
ALF Pm 5

1

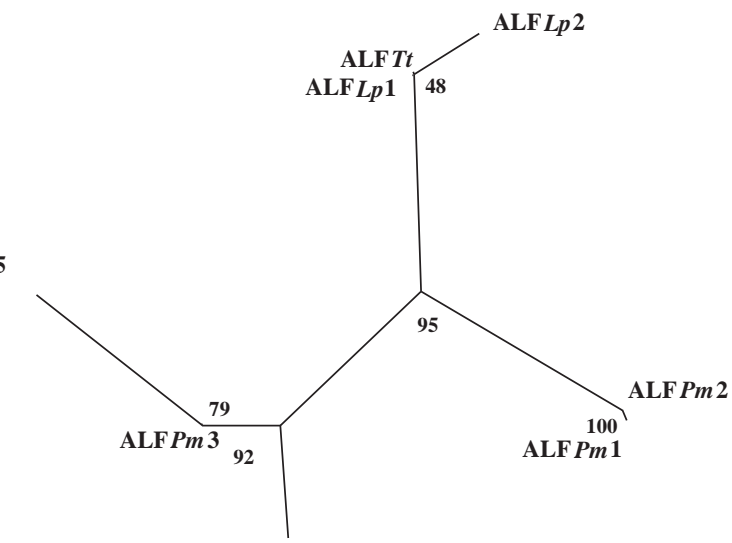

ALF Pm 4
Fig. 2. Pairwise alignments of deduced amino acid sequences of ALFPm 1 to 2 (A), ALFPm3 to 4 (B), ALFPm3 to 5 (C) and ALFPm4 to 5 (D). * indicates amino acid identity and $\cdot$ indicates amino acid similarity. A conserved core region (bold-italics) was found in ALFPm3, 4 and 5 but not in ALFPm1 and 2 (Aketagawa et al. 1986, Muta et al. 1987). A bootstrapped neighbor-joining tree summarizing relationships of ALFPm, ALFLp1, ALFLp2 and ALFTt is illustrated (E). Values at the node represent the percentage of times that the particular node occurred in 1000 trees generated from bootstrapping of the original amino acid sequences $($ L $p=$ Limulus polyphemus, $\mathrm{Tt}=$ Tachypleus tridentratus Pm = Penaeus monodon) 


\section{A}

penPm3a penPm3b penPm3c pen $L v 2 a$ penLv3a

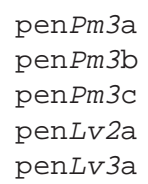

B

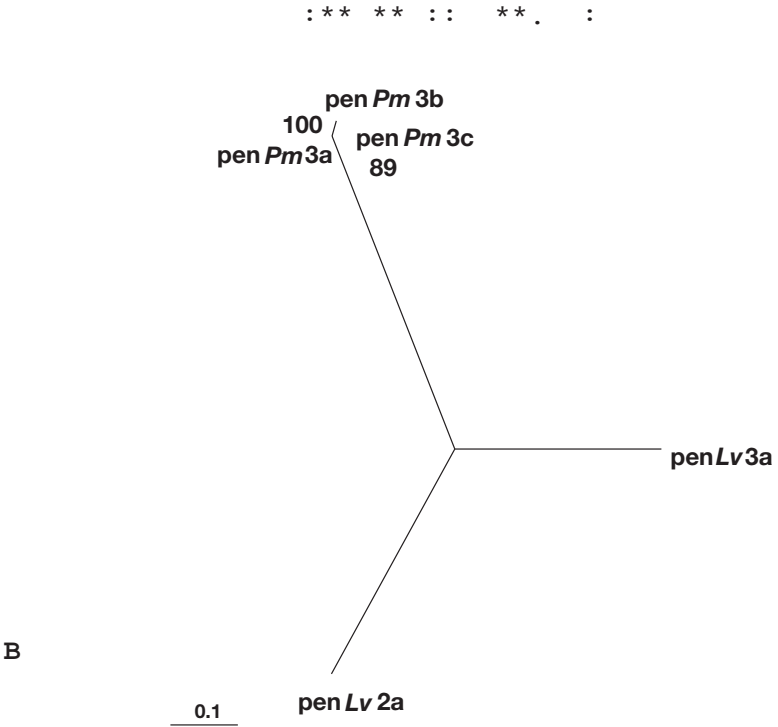

signature domain are primarily secreted proteinase inhibitors (Larsen et al. 1998). Proteinase inhibitors in the hemolymph of shrimp regulate the proteinase initiated host defense cascades (e.g. coagulation and prophenol oxidase or proPO systems) against bacterial and fungal pathogens (Bartlett et al. 2002).

Phylogenetic analysis clearly indicated monophyletic cladding of crustin families born after gene duplication and showed that crustin homologues in Penaeus monodon fell into 2 different groups called A (crus $P m 1$ and 2 that were closely related to crus $L s 1$ ) and $\mathrm{B}$ (crusPm3 and 4 that were closely related to crus $L v$ and crus $L s 2)$. The gene tree also confirmed a distant relationship between crusPm1 to 4 and GAMPPm1 (Fig. 4B).

\section{Tissue distribution and expression of AMP transcripts in normal and challenged Penaeus monodon}

Tissue expression patterns for Penaeus monodon ALF, penaeidin, and crustin were similar (Fig. 5). They were constitutively expressed at high levels in hemo-
Fig. 3. Multiple alignments of penaeidin homologues in Penaeus monodon (penPm3a, 3b and 3c) and those in Litopenaeus vannamei (pen $L v 2 \mathrm{a}$ and pen $L v 3 \mathrm{a}$, Destoumieux et al. 2000) (A). * indicates amino acid identity and - indicates amino acid similarity. The putative signal peptides and cleavage site are underlined and indicated by an arrowhead, respectively. The conserved PRP motifs are bold and the boxes indicate conserved cysteine residues. The different amino acids (black boxes) were found at residues 34 and 64 . A bootstrapped neighbor-joining tree summarizing relationships of pen $P m$, pen $L v 2$ a and pen $L v 3$ a is illustrated (B)

cytes. Lower levels of mRNA expression were found in hearts, gills, intestines and lymphoid organs and no transcript was detected in the hepatopancreas. Results were concordant to those found in other arthropods where hemocytes are the major sites of AMP synthesis (Iwanaga \& Kawabata 1998). Secondary expression sites such as intestines or gonads have been found for antibacterial peptides in in-sects (Hoffmann et al. 1997, Manetti et al. 1998). In Litopenaeus vannamei, penaeidin mRNAs were also detected mainly in hemocytes (Destoumieux et al. 2000, Munoz et al. 2002).

Comparison of expression levels of Penaeus monodon AMP (Table 2) revealed that crustin expression was highest in unchallenged $P$. monodon followed by penaeidins and ALF. Upon challenge with Vibrio har$v e y i$, the expression level of ALFPm significantly increased within $3 \mathrm{~h}$ post-injection $(\mathrm{p}<0.05)$ and returned to normal at $48 \mathrm{~h}$ post-injection $(\mathrm{p}<0.05$, Table 2 and Fig. 6A). The highest transcriptional level of ALFPm was observed at $6 \mathrm{~h}$ after $V$. harveyi injection (1.6 fold above that of normal shrimp).

In contrast, injection of Vibrio harveyi caused significant decreases of crustin and penaeidin expression in 
A

crusPm2

crusPm 1

crusPm3

crusPm4

crusLs 1

crusLs2

crusLV

crusPm2

crusPmI

crusPm3

crusPm4

crusLs 1

crusLs2

crusLV

crusPm2

crusPmI

crusPm 3

crusPm4

crusLs 1

crusLs2

crusLV

crusPm2

crusPmI

crusPm3

crusPm4

crusLs 1

crusLs2

crusLV

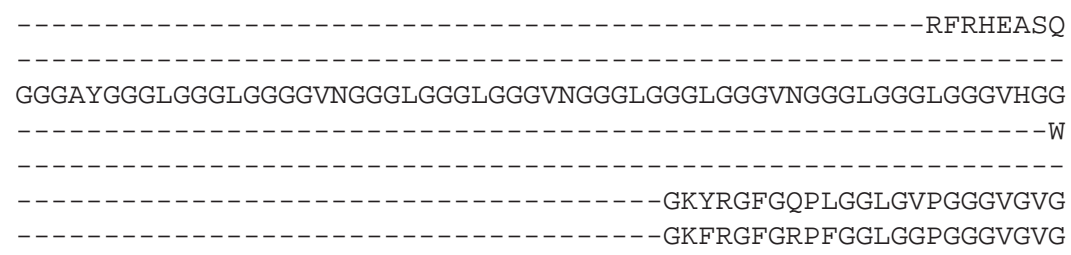

FTGFRSHSFRKHLAVVSAHGGRP GARP GGFPAGVP GGFP GGVP GEFPAP HLGGF LSVTAP -------------------QSWHGGRP GGFP GGGRP--GGFP GGGRP GGRP GGFP SVTAP GLGGGLGGGVNGGGLGGGVHGGGLGGGLGGGLSGGLGGGLGRPGGGLGRPGGGLRP GSRG RFRGGVNGGGLGGGLGGGVHGGGLGGGLGGGLSGGLGGGLGRP GGGLGRP GGGLRP GSRG ------------------------ GP GGF S GGVP GGFP GGRP GGFP GGVP GGFP SATAP VGGGLGGGLGGGLGGGLGGGLGGGLGGLGGGLGGLGGGLGGGLGGGLGGGLGGGLGGSHG GG-------------------------------------FPGGGLGVGGGLGVGGGLGTG

PATCRRWCRTPEDAVYCCESKYEPEAPVGTKP LDCPRVRDTCPPVRFGGLAP-VTCSSDI PASCRRWCETPENAFY CCESRYEPEAPVGTKI LDCPKVRDTCPPVRF LAVEQPVPCSSDY PSTCRYWCTTPEGKQYCCEDKNEPEIPVGTKP LDCPQVR-TCPRFQGPP----VTCSHDF PSTCRYWCTTPEGKQY CCEDKNEPEIPVGTKP LDCPQVRP TCPRFQGPP----VTCSHDF PATCRRWCKTPENQAYCCETIFEPEAPVGTKP LDCPQVRP TCPPTRFG--GRPVTCSSDY TSDCRYWCKTPEGQAYCCESAHEPETPVGTKP LDCPQVRP TCPRFHGPP----TTCSNDY TSDCRYWCKTPEGQAYCCESAHEPETPVGTKP LDCPQVRP TCPRFHGPP----TTCSNDY

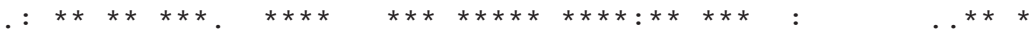

KCGGLDKCCFDRCLKEHYCKPPSFYSHFA-KCGGLDKCCFDRCLGQHYCKPPSFYEFFA-KCAGLDKCCFDRCLGEHVCKPPSFYGRNVKG KCAGLDKCCFDRCLGEHYCKPPSFYGRNVKG KCGGLDKCCEDRCLGEHVCKPPSFYSQFR-KCAGLDKCCFDRCLGEHYCKPP SFFGQQIFG KCAGLDKCCFDRCLGEHVCKPPSFFGSQVFG

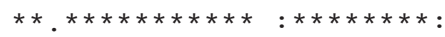

B

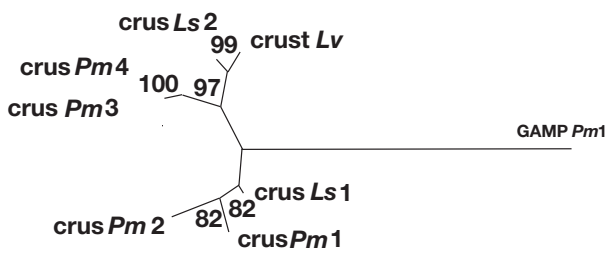

$\underline{0.1}$

Fig. 4. Multiple alignments of crustin homologues in Penaeus monodon (crusPms1 to 4) and those in Litopenaeus vannamei (crus $L v$ ) and L. setiferus (crusLs1 to 2, Bartlett et al. 2002). * indicates amino acid identity and $\cdot$ indicates amino acid similarity. Twelve conserved Cys residues (boxes) were found in the carboxy-terminal region of each putative crustin EST. A bootstrapped neighbor-joining tree summarizing relationships between crusPm, crusLs1, crusLs2, crusLV and a Glyrich antimicrobial peptide GAMPPm1 is illustrated (B) challenged Penaeus monodon within $3 \mathrm{~h}$ after injection of $V$. harveyi ( $\mathrm{p}<0.05$, Table 2, Fig. 6B,C). The lowest expression level of crusPm and penPm was observed at $6 \mathrm{~h}$ (0.16-fold below the normal level) and $12 \mathrm{~h}$ (0.35-fold below the normal level), respectively. Following this, crusPm and pen $P m$ levels significantly increased after $24 \mathrm{~h}$ post-injection $(\mathrm{p}<0.05)$ and were still significantly different from that of unchallenged $P$. monodon at $48 \mathrm{~h}(\mathrm{p}<0.05)$. Time-course transcriptional levels of proPO and heat shock protein (HSP) 70 were also examined using the same experimental procedures but the transcriptional levels were not sig- nificantly different between normal and challenged P. monodon throughout the test period $(\mathrm{p}>0.05$, data not shown).

Due to limited facilities, we did not include a control of shrimp injected with normal saline at different time intervals in the first experiment. Therefore, we cannot yet exclude the possibility that the genes expressed after Vibrio harveyi injection could possibly be induced by the injection of other materials and even neutral substances such as saline solution. Nonetheless, we performed an additional experiment to compare the expression at different time intervals 
$(0,3,6,12,24$ and $48 \mathrm{~h}$ post injection) of juvenile Penaeus monodon injected with $100 \mu \mathrm{l}$ of normal saline solution ( $\mathrm{N}=3$ for each group) with that of normal shrimp $(\mathrm{N}=3)$ and $V$. harveyi-injected
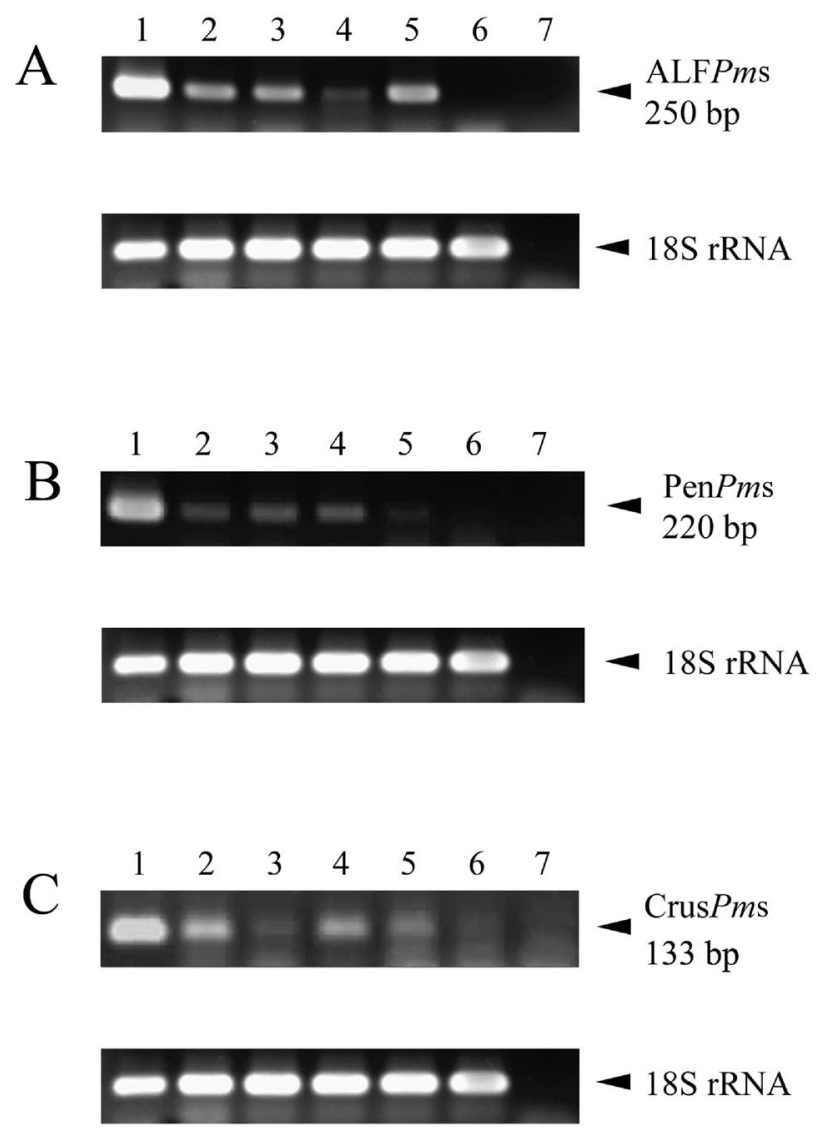

Fig. 5. Penaeus monodon. RT-PCR expression analysis of ALFPm (A), penPm (B) and crusPm (C) in hemocytes, the midgut, heart, gills, lymphoid organ, and hepatopancreas (lanes 1 to 6, respectively). Lane 7 was a negative control with no RNA template. The 18S rRNA gene product was included as control shrimp ( $0 \mathrm{~h}$ post injection, $\mathrm{N}=9$ ). No significant differences in expression of AMP transcripts between these groups were observed ( $p>0.05)$. Quantitative assay for measuring AMP transcripts by real-time PCR and determination of the number of hemocytes expressing AMP by in situ hybridization would be useful for further investigation of changes in AMP expression in response to microbial challenge.

There have been no reports on transcriptional regulation of ALF and crustins in other penaeid shrimp. However, Destoumieux et al. (2000) studied in vivo microbial experimental challenge using heat-killed bacteria (Aerococcus viridans and Vibrio alginolyticus) and the fungus (Fusarium oxysporum) and reported that transcriptional levels of penaeidins in Litopenaeus vannamei were not significantly increased by these microorganisms.

Our results suggest that expression of ALFPm was up-regulated whereas the expression of crusPm and pen $P m$ were down-regulated in vivo upon injection with the pathogenic Gram-negative bacterium, Vibrio harveyi. This may indicate some level of specificity in the innate immune system in Penaeus monodon since ALF is active against Gram negative bacteria like $V$. harveyi. Challenge of juvenile Litopenaeus vannamei with heat-killed microorganisms resulted in a 4 to 5 fold decrease of penaeidin mRNA levels at $3 \mathrm{~h}$ postinjection. This may have resulted from a partial decrease in penaeidin-producing hemocytes from the bloodstream or alternatively, from degranulation and release of penaeidins into the circulatory system (Destoumieux et al. 2000).

EST analysis is a potential approach for isolation and characterization of new AMP genes in Penaeus monodon where limited information at the genomic level is presently available. The presence of several isoforms of ALF, crustin and penaeidin ESTs in P. monodon reflects the diversity and possible broad spectrum of potential response against various types of microorganisms. Genome organization of these AMP genes should be further studied to clarify whether they are

Table 2. Penaeus monodon. A time-course analysis of ALFPm, crusPm and penPm expression levels using semiquantitative RT-PCR. The same superscripts between different time interval data are not significantly different $(p>0.05)$

\begin{tabular}{|c|c|c|c|c|c|c|}
\hline \multirow{2}{*}{ Gene } & \multicolumn{6}{|c|}{ Relative expression level* } \\
\hline & $0 \mathrm{~h}$ & $3 \mathrm{~h}$ & $6 \mathrm{~h}$ & $12 \mathrm{~h}$ & $24 \mathrm{~h}$ & $48 \mathrm{~h}$ \\
\hline ALFPms & $72.67 \pm 7.09^{\mathrm{a}}$ & $104.00 \pm 7.81^{b}$ & $116.33 \pm 23.18^{b}$ & $106.67 \pm 7.64^{b}$ & $101.33 \pm 8.145^{b}$ & $90.67 \pm 6.11^{\mathrm{ab}}$ \\
\hline CrusPms & $252.36 \pm 10.54^{\mathrm{a}}$ & $78.85 \pm 37.55^{\mathrm{bc}}$ & $39.61 \pm 12.42^{\mathrm{c}}$ & $43.62 \pm 12.44^{\mathrm{c}}$ & $90.57 \pm 11.31^{\mathrm{b}}$ & $154.92 \pm 38.14^{\mathrm{d}}$ \\
\hline PenPms & $137.33 \pm 17.62^{\mathrm{a}}$ & $76.00 \pm 12.12^{\mathrm{b}}$ & $57.00 \pm 11.36^{\mathrm{bc}}$ & $48.33 \pm 8.74^{\mathrm{c}}$ & $79.33 \pm 9.29^{b}$ & $107.67 \pm 23.01^{d}$ \\
\hline
\end{tabular}


encoded by single or multiple loci and to provide an understanding of their regulation in the shrimp immune response.
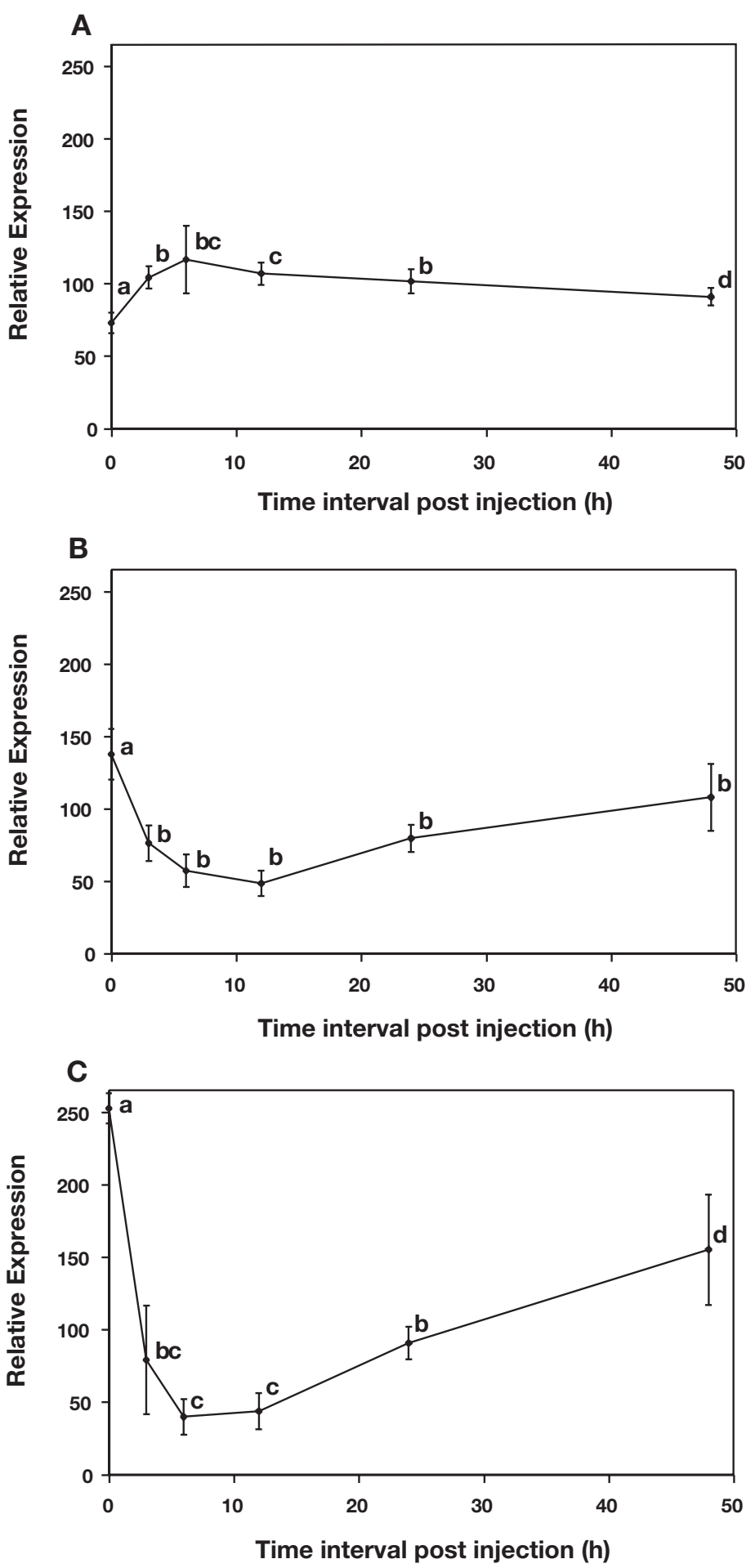

Fig. 6. Relative expression levels of (A) Penaeus monodon ALF, (B) penaeidins and (C) crustins at different time intervals after Vibrio harveyi challenge. Different letters between time interval data indicate significant differences $(p<0.05)$
Acknowledgements. We are grateful to Dr. E. Bachere (IFREMER/CNRS/Universite Montpellier 2, DRIM, Montpellier, France) for her useful advice and critical comments on this study. This work is supported by the Thailand National Center for Genetic Engineering and Biotechnology (BIOTEC) grant no. BT-B-06-2B-09-309 and the European Commission (INCO-DC) contract No. ICA4-CT-2001-10023, IMMUNAQUA and is partially supported by the Thai Ministry of University Affairs. We also thank the financial support from Chulalongkorn University through Shrimp Molecular Biology and Genomics Laboratory and the ThailandJapan Technology Transfer (TJTTP) program. A postdoctoral fellowship granted to P.S. by BIOTEC is also acknowledged.

\section{LITERATURE CITED}

Aketagawa J, Miyata T, Ohtsubo S, Nakamura T, Morita T, Hayashida H, Miyata T, Iwanaga S (1986) Primary structure of Limulus anticoagulant anti-lipopolysaccharide factor. J Biol Chem 261:7357-7365

Altschul SF, Madden TL, Schaffer AA, Zhang J, Zhang Z, Miller W, Lipman D (1997) Gapped BLAST and PSIBLAST: a new generation of protein database search programs. Nucleic Acids Res 25:3389-3402

Argue BJ, Arce SM, Lotz JM, Moss SM (2002) Selective breeding of Pacific white shrimp (Litopenaeus vannamei) for growth and resistance to Taura syndrome virus. Aquaculture 204:447-460

Austin B (1988) Aquatic Microbiology. Cambridge University Press, Cambridge

Bachere E, Mialhe E, Noel D, Boulo V, Moran A, Rodriguez $J$ (1995) Knowledge and research prospects in marine mollusk and crustacean immunology. Aquaculture 132: $17-32$

Bachere E, Destoumieux D, Bulet P (2000) Penaeidins, antimicrobial peptides of shrimp: a comparison with other effectors of innate immunity. Aquaculture 191:71-88

Bartlett TC, Cuthbertson BJ, Shepard EF, Chapman RW, Gross PS, Warr GW (2002) Crustin, homologues of an 11.5$\mathrm{kDa}$ antibacterial peptide, from two species of penaeid shrimp, Litopenaeus vannamei and Litopenaeus setiferus. Mar Biotechnol 4:278-293

Boman HG (1995) Peptide antibiotics and their role in innate immunity. Annu Rev Immunol 13:61-92

Bulet P, Hitru C, Dimarcq JL, Hoffmann D (1999) Antimicrobial peptides in insects; structure and function. Dev Comp Immunol 23:329-344

Cruciani RA, Barker JL, Zasloff M, Chen H, Colamonici O (1991) Antibiotic magainins exert cytolytic activity against transformed cell lines through channel formation. Proc Natl Acad Sci USA 88:3792-3796

Destoumieux D, Bulet $\mathrm{P}$, Loew D, Van Dorsselaer AV, Rodriguez J, Bachere E (1997) Penaeidins: A new family of antimicrobial peptides in the shrimp Penaeus vannamei (Decapoda). J Biol Chem 272:28398-28406

Destoumieux D, Bulet P, Strub JM, Dorsselaer AV, Bachere E (1999) Recombinant expression and range of activity of penaeidins, antimicrobial peptides from penaeid shrimp. Eur J Biochem 266:335-346

Destoumieux D, Munoz M, Cosseau C, Rodriguez J, Bulet P, Comps M, Bachere E (2000) Penaeidins, antimicrobial peptides with chitin-binding activity, are produced and stored in shrimp granulocytes and released after microbial challenge. J Cell Sci 113:461-469 
Duncan DB (1955) Multiple-range and multiple F test. Biometrics 11:1-42

Felsenstein J (1993) Phylip (Phylogenetic Inference Package) version 3.5c. Department of Genetics, University of Washington, Seattle

Goyard E, Patrois J, Peignon JM, Vanaa V, Dufour R, Viallon J, Bedier E (2002) Selection for better growth of Penaeus stylirostris in Tahiti and New Caledonia. Aquaculture 204: 461-468

Gross PS, Bartlett TC, Browdy CL, Chapman RW, Warr GW (2001) Immune gene discovery by expressed sequence tag analysis of hemocytes and hepatopancreas in the Pacific white shrimp, Litopenaeus vannamei, and the Atlantic white shrimp, L. setferus. Dev Comp Immunol 25:565-577

Hancock REW, Diamond G (2000) The role of cationic antimicrobial peptides in innate host defences. Trends Microbiol 8:402-410

Hancock REW, Scott MG (2000) The role of antimicrobial peptides in animal defenses. Proc Natl Acad Sci USA 97: $8856-8861$

Hetru C, Hoffmann D, Bulet P (1998) Antimicrobial peptides from insects. In: Brey PT, Hultmark D (eds), Molecular mechanisms of immune responses in insects. Chapman \& Hall, London, p 40-66

Hetzel DJS, Crocos PJ, Davis GP, Moore SS, Preston NC (2000) Response to selection and heritability for growth in the Kuruma prawn, Penaeus japonicus. Aquaculture 181: $215-223$

Hoess A, Watson S, Siber GR, Liddington R (1993) Crystal structure of an endotoxin-neutralizing protein from the horseshoe crab, Limulus anti-LPS factor, at $1.5 \AA$ resolution. EMBO J 112:3351-3356

Hoffmann JA, Reichart JM (1997) Drosophila immunity. Trends Cell Biol 7:309-316

Iwanaga S, Kawabata S (1998) Evolution and phylogeny of defense molecules associated with innate immunity in horseshore crab. Front Biosci 3:973-984

Jarayabhand P, Uraiwan S, Klinbunga S, Tassanakajon A, Srimukda P, Pattanachan P, Panakulchaiwit R, Menasveta P (1998) Estimated heritabilities for early growth rate of the black tiger prawn, Penaeus monodon, Fabricius. In: Flegel $\mathrm{T}$ (ed) Proceedings to the special session on advances in shrimp biotechnology, the fifth asian fisheries forum: international conference on fisheries and food security beyond the year 2000. 11-14 November 1998. Chiangmai, Thailand, p 67-70

Larsen M, Rressler SJ, Lu B, Gerdes MJ, McBride L, Dang TD, Rowley DR (1998) Molecular cloning and expression of ps20 growth inhibitor - a novel WAP-type 4 disulfide core domain protein expressed in smooth muscle. J Biol Chem 273:4574-4584

Lee SY, Lee BL, Soderhall K (2002) Processing of an antibacterial from hemacyanin of the freshwater crayfish Pacifastacus lenticulus. J Biol Chem 278:7927-7933

Lehrer RI, Ganz T (1999) Antimicrobial peptides in mammalian and insect host defense. Curr Opin Immunol 11: $23-27$

Lemaitre B, Reichhart JM, Hoffmann JA (1997) Drosophila host defense: differential induction of antimicrobial peptide genes after infection by various classes of microorganisms. Proc Natl Acad Sci USA 94:14614-14619

Lightner DV, Redman RM (1998) Strategies of viral control of diseases of shrimps in the Americas. Fish Pathol 33: $165-180$

Manetti AGO, Rosetto M, Marchini M (1998) Antibacterial peptides of the insect reproductive tract. In: Brey PT, Hult- mark D (eds) Molecular mechanisms of immune responses in insects. Chapman \& Hall, London, p 67-91

Marone M, Mozzetti S, Ritis DD, Pierelli L, Scambia G (2001) Semiquantitative RT-PCR analysis to assess the expression levels of multiple transcripts from the sample. Biol Proced Online 1:19-25

Morita $\mathrm{T}$, Ohtsubo $\mathrm{S}$, Nakamura $\mathrm{T}$, Tanaka $\mathrm{S}$, Iwanaga $\mathrm{S}$, Ohashi K, Niwa M (1985) Isolation and biological activities of Limulus anticoagulant (anti-LPS factor) which interacts with lipopolysaccharide (LPS). J Biochem 97: $1611-1620$

Munoz M, Vandenbulcke F, Saulnier D, Bachere E (2002) Expression and distribution of penaeidin antimicrobial peptides are regulated by hemocyte reaction in microbial challenged shrimp. Eur J Biochem 269:2678-2689

Murakami T, Niwa $M$, Tokunaga $F$, Miyata $T$, Iwanaga $S$ (1991) Direct virus inactivation of tachyplesin I and its isopeptides from horseshoe crab hemocytes. Chemotherapy $37: 327-334$

Muta $T$, Miyata $T$, Tokunaga $F$, Nakamura $T$, Iwanaga $S$ (1987) Primary structure of anti-lipopolysaccharide factor from American horseshoe crab, Limulus polyphemus. J Biochem (Tokyo) 101:1321-1330

Pan J, Kurosky A, Xu B, Chopra AK, Coppenhaver DH, Singh IP, Baron S (2000) Broad antiviral activity in tissues of crustaceans. Antivir Res 48:39-47

Raikhel NV, Lee HI, Broekaert WF (1993) Structure and functions of chitin-binding proteins. Annu Rev Plant Physiol Plant Mol Biol 44:591-615

Relf JM, Chisholm RS, Kemp GD, Smith VJ (1999) Purification and characterization of a cysteinrich $11.5-\mathrm{kDa}$ antibacterial protein from the granular hemocytes of the shore crab, Carcinus maenas. Eur J Biochem 264:350-357

Rojtinnakorn J, Hirono T, Itami T, Takahashi Y, Aoki T (2002) Gene expression in hemocytes of kuruma prawn, Penaeus japonicus, in response to infection with WSSV by EST approach. Fish Shellfish Immunol 13:69-83

Rosenberry B (2003) World shrimp farming 2003. Shrimp News International, San Diego

Saitou N, Nei M (1987) The neighbor-joining method: a new method for reconstructing phylogenetic trees. Mol Biol Evol 4:406-425

Schnapp D, Kemp GD, Smith VJ (1996) Purification and characterizaion of a proline-rich antibacterial peptide, with sequence similarity to bactenecin-7, from the hemocytes of the shore crab, Carcinus maenas. Eur J Biochem 240:350-357

Shai Y (1999) Mechanism of the binding, insertion and destabilization of phospholipid bilayer membranes by alpha-helical antimicrobial and cell non-selective membrance-lytic peptides. Biochim Biophys Acta 1462: $55-70$

Steel RGD, Torrie JH (1980) Principles and procedures of statistics. McGraw-Hill, New York

Supungul P (2002) Identification and characterization of cDNA encoding immune related proteins in the hemocytes of black tiger shrimp Penaeus monodon by expressed sequence tag. $\mathrm{PhD}$ thesis, Chulalongkorn University, Bangkok

Supungul P, Klinbunga S, Pichayakura R, Jitrapakdee S, Hirono I, Aoki T, Tassanakajon A (2002) Identification of immune related genes in hemocytes of the black tiger shrimp Penaeus monodon. Mar Biotechnol 4:487-494

Thompson JD, Gibson TJ, Plewniak F, Jeanmougin F, Higgins DG (1997) The CLUSTALX windows interface: flexible strategies for multiple sequence alignment aided by quality analysis tools. Nucleic Acids Res 25:4876-4882

Yeaman MR, Yount NY (2003) Mechanisms of antimicrobial 
peptide action and resistance. Pharmacol Rev 55:27-55

Wainwright NR, Miller RJ, Paus E, Novisky TY, Fletcher MA, McKenna TM, Williams T (1990). In: Nowotny A, Spitzer JJ, Ziegler EJ (eds) Cellular and molecular aspects of endotoxin reaction. Elsevier Science Publishers, Amsterdam

Withyachumnarnkul B, Boonsaeng W, Flegel TW, Panyim S,

Editorial responsibility: Timothy Flegel,

Bangkok, Thailand
Wongteerasupaya C (1998) Domestication and selective breeding of Penaeus monodon in Thailand. In: Flegel $\mathrm{T}$ (ed) Proceedings to the special session on advances in shrimp biotechnology, the fifth asian fisheries forum: international conference on fisheries and food security beyond the year 2000. 11-14 November 1998. Chiangmai, Thailand, p 67-70

Submitted: October 10, 2003; Accepted: March 22, 2004

Proofs received from author(s): September 6, 2004 